\title{
オーストラリアにおけるエコッーリズム認証制度（NEAP）の仕組みと特徵について \\ System and Characteristics of National Ecotourism Accreditation Program in Australia
}

小菅 貴史* 古谷 勝則* 親泊 素子**

\section{Takashi KOSUGE Katsunori FURUYA Motoko OYADOMARI}

\begin{abstract}
NEAP (National Ecotourism Accreditation Program) in Australia started in 1996. This is the first ecotourism accreditation program in the world. In this study, the system and characteristics of NEAP have been clarified. The study was conducted mainly through worldwide literature research and perusal of the official website. In addition, field survey and interviews were conducted for 10 days from March 3rd to 12th in 2010. Development of NEAP was initiated by Ecotourism Association of Australia together with related industries and the government. NEAP is a program which accredits accommodation facilities, tours, and attractions in nature areas, based on a standard established by NEAP itself. Four hundred and twenty-three quality ecotourism products have been accredited as of January 2010. The increasing number of accredited ecotourism products has been contributing to raise consciousness among the tourism related industries. As a result of study on benefits of NEAP, the system where environment conservation translates to economical profitability has been revealed. The relationship with economy is important for ecotourism, which strives for sustainable developments. On the other hand, it was revealed that there were cases where understanding about NEAP was lacking, based on field study results and interviews with tourists. Also, some facilities had problems with facility maintenance related to environmental consciousness.
\end{abstract}

key word : Australia, Ecotourism, NEAP, EcoCertification Program, Environmental Preservation, Sustainable キーワード：オーストラリア，エコツーリズム，NEAP，エコ認証制度，環境保全，持続可能

\section{1. はじめに}

エコツーリズムは、自然環境や文化歴史的資産を保全しつつ、 観光事業を軸にして地域産業を活性化し、地域の厚生水準を高め ていく極めて現実的要請に即した施策である (海津,2008) ${ }^{1)}$ 。エ コツーリズムの運用については、発展途上国で行われ先進国でも 利用されるようになってきている。日本においても環境省が中心 となりエコツーリズムを浸透させるための体制づくりを進めてい る。しかし、エコツーリズムは、環境に配慮した持続的な観光と されながらもその効果や実態があまり知られていない。概念や定 義はあるが、さまざまな解釈・表現がありまとまりがなく、エコ ツーリズム企画商品においても差があり、旅行者の期待が裏切ら れる実態もある。そのため、エコツーリズムの正しい理解を促し、 認知度を高めていくことが必要である（下村,2004） ${ }^{2)}$ 。エコツー リズムであっても、環境に配慮した持続的な観光を目指していな い商品がある。このような実態に対して、商品企画から宣伝、募 集展開の流れでのエコツーリズムの役割を考える必要がある。 エコツーリズム先進国と言われるオーストラリアでは、エコツ ーリズム商品に対して認証を行うユニークな制度＝エコツーリズ 么認証制度 (National Ecotourism Accreditation Program, 本論 文ではNEAP 認証制度と記載) を設け、適切な運用・監視・管理を 進めている。この制度は、商品に対してある規格基準を設け、観 光業者が取得し、商品設計に表現することで、旅行者が安心して 質の高い商品を選択できる環境を作り出している。現在、絶烕種 の動植物が増え、今後地球の豊かな自然環境、野生生物等の保護 が必要な時であり、自然環境と人との共存は極めて重要と考える。

NEAP 認証制度に関する既存研究として、Ralf C. Buckley (2001） ${ }^{3)}$ が制度の概要を、Guy Chester and Alice Crabtree $(2002)^{4)}$ は制度改訂の変遷について述へ、J.-P.lssaverdis (2001) 5) は制度の内容からビジネスや環境について要点を述べ、John Jenkins and Stephen Wearing (2003) ${ }^{6)}$ は制度によってエコツ ーリズム産業発展と環境保護に大きく貢献していると述べている。 最近では、Rik Thwaites（2007） ${ }^{7)}$ が制度内容、運営組織につい
て述べている。日本では、小林寛子 $(2002)^{8)}$ が NEAP 認証制度 と世界の環境認証について事例を述べ、またスー・ビートン (2002) ${ }^{9}$ は、豊富な事例、研究結果を通してオーストラリアエ コツーリズム関わる問題点を分かりやすく述べ、小林英俊 (2006) 10) はエコツーリズムの事例分析から、NEAP 認証制度を取り上げ管 理・運営手法について述べている。しかし、これまでの研究内容 は、NEAP 認証制度の概要や運営を個別の事例から述べているもの が多い。NEAP 認証制度の仕組みと特徵を、成立の過程や認証を受 ける商品、認証の実態から考察したものは少ない。

本研究は、世界で最初のエコツーリズム認証制度ともいわれて いるオーストラリアの NEAP 認証制度の仕組みと特徴を明らか にすることを目的とした。認証制度の仕組みと特徴は、制度の成 立過程と商品の認証実態から考察した。NEAP 認証制度は NEAPIII (2003) の改正時点でEcoCertification Programに名称変更され たが、本論文ではNEAP 認証制度と呼ぶことにした。

\section{2. 研究の方法}

\section{(1) オーストラリアの概要}

正式名称 は、オーストラリア連邦 ${ }^{11^{\prime}}$ で 6 つの州 ${ }^{12)}$ と 2 つの 特別地域 ${ }^{13}$ から構成される連邦国家である。南半球に位置し、人 口約 2, 137 万人(2008) で日本の約 6 分の 1 、国土面積 769 万 2,024 平方キロメートルで世界第6位の面積で日本の面積の約 20 倍の広 さを保有する ${ }^{14)}$ 。GDP は 9, 248 億ドル (2008 年 18 位)、1 人当た り 48, 951 ドル (2008 年 14 位) ${ }^{15)}$ と世界的に見ると豊かな国とい える。日本の GDP と比較すると約 5 分の 1 倍だが、 1 人当たりの GDP 比率では約 0.9 倍になり 1 人当たりに換算すると日本とほと んど変わらない。またオーストラリアは、約 6 万年以上も前から 人類が生活していたといわれ歴史が深く、大陸には雄大な自然が 存在し、オーストラリアでしか見ることのできないコアラ、カン ガルーなどがいることで多くの海外観光客が訪れている。

*千葉大学大学院園芸学研究科 $* *$ 江戸川大学社会学部 


\section{（2）研究方法}

本研究では、オーストラリにおける NEAP 認証制度の仕組みと特 徵を明らかにするために、国内外の文献調査や公式Web ページの 閲覧を中心に進めた。文献調査では、オーストラリアのエコツー リズムに関する既往文献に加え、NEAP 認証マニュアル第2 版、第 3 版を収集し参考にした。さらに、2010 年 3 月 3 日〜 12 日までの 10 日間の現地調査とインタビュー調査を行った。現地調査では、 本研究の対象となる商品 (ツアー16' 、宿泊施設 ${ }^{17}$ )、アトラクシ ヨン $\left.{ }^{18}\right)$ を 3 ヶ所選定し、情報収集を行った。現地調査は、クイ ーンズランド州のゴールドコーストとブリスベンの地域を訪れた。 また対象となる商品を管理するスタッフやッアーガイド、旅行者、 レンジャーからインタビューを行った。

\section{3. 結果と考察}

NEAP 認証制度の仕組みと特徵について検討するために、制度の 目的、取り組み、歴史変遷について、認証商品の現地調査、イン タビュー調査、関連文献資料より述べた。

\section{(1) NEAP ${ }^{19}$ 認証制度}

エコツーリズムと言う言葉が普及するにつれて 1991 年に非営 利団体としてオーストラリアエコツーリズム協会（本論文では $\mathrm{EAA}^{20)}$ と記載）が設立された ${ }^{21)}$ 。しかし、国内でエコツーリズム、 エコッアー、エコロッジという言葉が広がり、よく似ていて見分 けがつかないものが多数出てきたことでエコツーリズムの質の低 下が危惧された。そこで優良商品の差別化を図るともに、業界全 体のレベルの向上を図るために EAA とオーストラリアツアーオペ レーターネットワーク (ATON /VTOA) ${ }^{22)}$ が共同で開発し、連邦政 府からの資金援助を得て 1996 年世界で初めて、優れたエコツーリ ズム商品を認証する制度（NEAP）を設け、認証を開始した。これ らは基本的に自然地域での取り組みにおける商品（宿泊施設、ツ アー、アトラクション）を組織が定める基準項目において比較評 価、認証を行う自然環境の保護を目的とした取り組み制度である。

この制度の管理・運営は、連邦政府からの資金援助々認証費用 ならびに認証業者の年会費によってEAA が行っている。認証によ って自然保護地域での良質な管理・対策によって利用者に真の商 品を認証するものとし、1996 年当初、認証商品は 200 個以上評価 され ${ }^{23}$ 、現在では 423 個（2010 年 1 月時点）の評価を受け、評価 基淮の改良は、常に見直され更新されている。

NEAP の目指している目的は、「エコツーリズムと他の観光産業 と係わることで社会的、文化的な責任を負い、経済的にも実行可 能で、継続的な環境保護のリーダーになるように手助けする ${ }^{24)}$

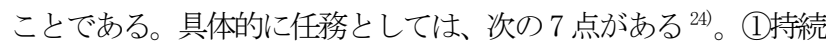
可能な観光の基淮を開発し、採用する。(2)観光産業の中で働いて いる人のプロフェッショナルを増やす。(3保護地域ですでに完成 され作用している政策や方法を合理化する。(4)その場所について オペレーターのインタープリテーションの質の改良を手助けする。 (5)持続的可能な実行のためオペレーターの財政的な実現性とポジ ショニング改善をする。6 保護対策と計画に貢献し、地元地域の 利益に係わり、提供する。7 持続的可能な基準の認識が増加する ようマーケティングすることである。

\section{（2）オ一ストラリアエコツーリズム協会 (EAA) の取り組み}

オーストラリアのエコツーリズムを促進していくことを目的に 1991 年に設立された EAA は、オーストラリア連邦政府やクイーン ズランド州政府の支援で設立された非営利団体である。エコツー リズムを利用・浸透させることで貴重な自然や文化を保護し、地 域社会への利益をもたらし持続的な発展を望むものである。設立 当時の会員数は 60 件程度であったが、 2003 年にはその数を約 500 件までに増やしている ${ }^{24)}$ 。会員は、エコツーリズム経営者、旅行 業者、民間団体、政府各機関ならひ教育機関やエコツーリズムに
関心を寄せる団体である。彼らがエコツーリズムに関する調査研 究を実施し、インターネットを通じてエコツーリズムのマーケテ イングの促進や NEAP 認証商品の広報及び取得拡大を呼びかけ、地 方支部の設立などにも力を入れた活動を行っている ${ }^{24)}$ 。観光業に 関わるツアーオペレーターに対して、EAA の認証制度は他に NEAP 認証（エコツーリズム商品）、エコガイド認証（ツアーガイド）、 文化保護認証、気候影響評価認証（ビジネス）などがある。本研 究で対象とした、NEAP 認証 (エコツーリズム商品) は、世界初の 自然地域のエコツーリズム商品に関して認証を行う制度である。 商品を認証することで持続可能な管理、地元への貢献に繋がる効 果がある。エコガイド認証（ツアーガイド）は、2000 年に開始さ れたオーストラリアのトップガイドに与えられる認証である。エ コガイド認証によって公認されたガイドは、安全で、文化的に敏 感で環境面で持続可能な方法を知り、専門的で上質エコツーリズ ム体験を提供している。文化保護認証は、2003 年に開始され、先 住民の文化遺産や生活文化を尊重し、保護に繋がるように認証さ れている。認証がある商品は、先住民の工芸品として本物である ことが保証される。気候影響評価認証 (ビジネス) は、2009 年に 開始されエネルギー消費量、二酸化炭素排出量を減らす努力を格 付けて認証するものである。

（3）オーストラリアエコツーリズム協会 (EAA) の成立と発展 1）オーストラリアエコツーリズム協会（EAA）の発足 エコツーリズム産業の発達と人気に乗じ、不適切な行いをする ッアーオペレーター ${ }^{25)}$ が出てきたことで 1991 年にEAA を発足し、

（表 - 1）同年オーストラリア、ブリスベンのクイーンズランド 大学で様々な立場の人達からなるエコツーリズム会議が実施され た 26)。その会議で Janet Richardson は、どのようにエコツー リズムの関係を組み立てるかを提起した ${ }^{27)}$ 。それは環境保護の 実施というよりも、エコツーリズム産業の活発な促進を目的にし たためツアーオペレーターが急増した ${ }^{28)}$ 。

2) NEAP 認証制度の検討開始

1993 年にクイーンズランド州北部のポートダクラスで NGO や保護団体、政府機関など学術的に幅広い分野の 300 人以上の代 表が出席し、NEAP 認証制度の開発、支援について討議された 28 )。エコツーリズムの用語は、メディアに取り上げられ始め、注 目され理解されるようになった。

会議内容より、エコツーリズム協会はエコツーリズムの方針を 定め発展、成長を目指寸ことにした。連邦政府は、シドニーを活 動拠点としていた Manidis Roberts ConsultantsにNEAP 認証 制度計画について調査させ、その後オーストラリアのエコツーリ ズム財政援助案を計画した ${ }^{27)}$ 。援助策は、連邦政府より 6 万ド ルを拠出し、EAA とオーストラリアツアーオペレーターネットワ ーク（ATON /VTOA）の連携、協力により観光事業認証計画を 開発させることにし、それが NEAP 認証制度発足のスタートであっ た。

\section{3）政策の実施と連邦政府からの支援}

1994 年に国家エコツーリズム計画としてオーストラリア国内 外の観光、エコツーリズムの発展のための構造を組み立てた ${ }^{29)} 。$ 1995 年から毎年エコツーリズム会議が開かれるようになり、その 年はノーザンテリトリーのアリススプリングスで開かれ 30)、 徐々に NEAP 認証制度の発展が図られた。オーストラリア観光 省では、生態学的に持続可能な観光開発計画が引き続き検討され た。1994 年から 97 年の 4 年間に長期的な自然保護、管理を狙つ た政府政策の実施と、援助金約 1,000 万 Au $\$$ (約 500 万 US\$） が使用されたことで国際的にもオーストラリアのエコツーリズム は注目された ${ }^{31)}$ 。

4) NEAP 認証制度の開始

1996 年は、エコツーリズム会議がオーストラリア南部のカンガ 
表-1 オーストラリアエコツーリズム協会 (EAA) の変遷

\begin{tabular}{|c|c|}
\hline 年 & 出来事 \\
\hline 1991 & $\begin{array}{l}\text { 1) オーストラリアエコツーリズム協会 (EAA) の発足 } \\
\text { ，観光保護よりエコツーリズム産業の促進化 } \\
\end{array}$ \\
\hline 1993 & \begin{tabular}{|l} 
2) NEAP認証制度の検討開始 \\
$\rightarrow$ 環境保護を重点に制度化検討、連邦政府からの \\
援助で観光事業認証計画開発
\end{tabular} \\
\hline 1994 & $\begin{array}{l}\text { 3) 政策の実施と連邦政府からの支援 } \\
\rightarrow \text { 国家エコツーリズム計画を構築し } \\
\text { 観光計画範囲を拡大し推進 } \\
\end{array}$ \\
\hline 1996 & \begin{tabular}{|l} 
4) NEAP認証制度の開始 \\
$\rightarrow$ 制度を実行可能の形にするために基準内容の見直し実施
\end{tabular} \\
\hline $\begin{array}{l}2000 \\
2001\end{array}$ & \begin{tabular}{|l}
$\mid$ 5) NEAP II とエコガイド計画の導入 \\
$\rightarrow$ NEAP認証制度改訂、第2期「NEAP II 」に改名 \\
Nature and Ecotourism Accreditation Program \\
） 商品適性に新しいカテゴリー導入 \\
$\rightarrow$ 新しい料金システム導入 \\
$\rightarrow$ NEAPエコガイド認証計画の開発 \\
\end{tabular} \\
\hline $\begin{array}{l}2004 \\
2005 \\
\end{array}$ & \begin{tabular}{|l} 
6) 審査条項の検討・開発 \\
$\rightarrow$ 第3期「NEAPIII」エコ認証制度 \\
EcoCertification Programに改名 \\
$\rightarrow 2004$ 年審査条項案の開発 \\
$\rightarrow 2005$ 年オンライン申請にて認証の促進化
\end{tabular} \\
\hline
\end{tabular}

ルー島で開かれ ${ }^{30)}$ 、加盟する会員数は増加した ${ }^{32)}$ 。この年EAA が今まで進めてきたエコツーリズム商品に関する第 1 期 NEAP

(National Ecotourism Accreditation Program) 認証制度を本格 的に開始した ${ }^{33)}$ 。最初の評価の種類は、エコツーリズムとアド バンスエコツーリズムの 2 種類であった。制度設立に向けた検討 段階では、制度基準内容が粗末であり、管理運営費用も高く設定 され、規模の小さい観光業者が参加するのは厳しかった ${ }^{31) 。 し ~}$ かし政府の資金的な援助により、この運営は実行可能になり、制 度は開始された ${ }^{31)}$ 。

5) NEAP II とエコガイド計画の導入

2000 年に NEAP の名前を National から Nature に変更し ${ }^{34)}$ 、 第 2 期 NEAP II (Nature and Ecotourism Accreditation Program）とした。NEAPIIでは、評価の種類に新しくネイチャ ーツーリズムを組み入れ ${ }^{35)}$ 、料金システムも見直し、年会費を 含む認証料金は以前より安くなった。販売促進に Web ページを 設けた策も加え、制度が改正された ${ }^{36)}$ 。更に、この制度改正で はガイドの質の向上を目指すためにガイド認証制度も導入された。 オーストラリアエコツーリズム発展に関連した国際的な動きとし ては、1999 年の国連環境会議 (UNEP)、2002 年の国際エコツ ーリズムの年（IYE : International Year of Ecotourism）があ った。クイーンズランド州政府からも 2 万US $\$$ の資金援助を受け、 自然保護地域の管理者育成、教育をすることが図れた ${ }^{32)}$ 。そし て 2002 年 EAA は、クイーンズランドの旧活動拠点をブリスベン 繁華街、商業中心地区の大きな建物に移動し、活動内容も NEAP 認証制度の強化、拡大とエコガイド認証制度に注目した展開を推 進した ${ }^{37)}$ 。

2002 年に実施したEAA の調査では、133社のうち54\%が NEAP 制度の将来への展望が時代と共に進化することを期待しているこ とが分かった ${ }^{38)}$ 。従来の NEAP 認証制度で指摘される点は、ツア 一オペレーターが作成する申請書に様々な基準があり複雑である ことで作成にも時間がかかり、その割に成果につながらない内容 であった。この手続きの過程ですでに混乱しストレスが溜まり、 完成するための意欲を妨げる存在になっていた ${ }^{38)}$ 。NEAPII では 見直され、NEAP I より分かりやすく改良された。しかしNEAP II で も申請と基準の運用は、業者の大小によって、必ずしも十分配慮 さたわけではなかった。

6）審査条項の検討・開発

2003 年 NEAP II は、第 3 期として見直され、NEAPIIIエコ認証制

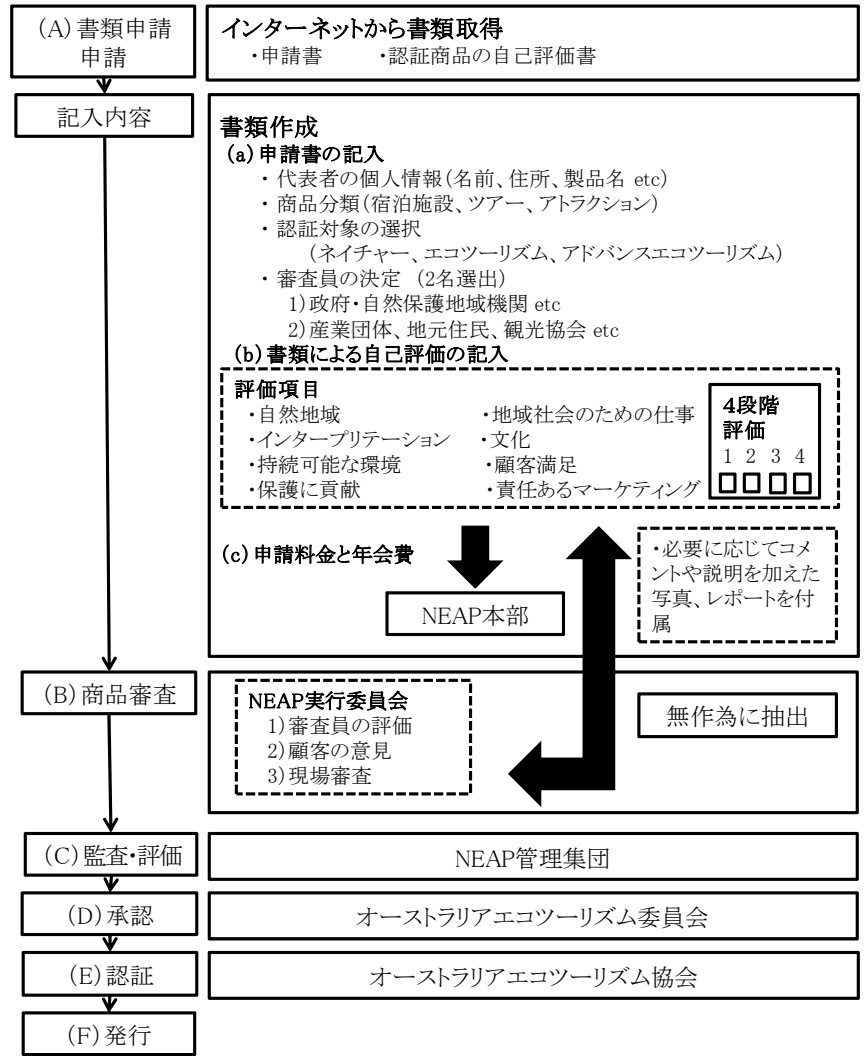

出典: EAA (2003) Nature and Ecotourism Certification Program Second edition, Rik Thwaites (2007) The Australian EcoCertification Program (NEAP): Blazing a Trail for Ecotourism Certification, but Keeping on Track?, Chapter22, pp.435 463.

\section{図-1 申請から認証までの流れ}

度（EcoCertification Program）と改称された ${ }^{39)}$ 。の改称は、 2002 年 5 月ケベック州の世界エコツーリズム会議 (WES: World Ecotourism Summit) で話題にされた。この会議では、主に、 Certification と Accreditation の用語の使用方法の問題が指摘さ れた 40)。Ralf Buckley 氏によると、オーストラリアの NEAP は、Accreditation というより環境保護の活動に対しての Certification として考慮されたと考えられている ${ }^{41)}$

内容も認証における審査委員に第 3 者審査委員を加入させ、 2004 年に審査委員の審査条項プログラムの開発も行った ${ }^{37) 。}$ 2005 年には、パソコンを利用したオンラインでの申請書作成、申 請認証できるシステムを設け NEAP 認証制度をより利用しや寸 くさせることで促進させた ${ }^{38)}$

2010 年の会議は、10 月クイーンズランドのサンシャインコー ストで開催した ${ }^{42}$ )。会議には、エコツーリズム関係者 (経営者、 政府、企業団体、保護団体など）が参加し、事例研究、業界の現 状などを討論が行われ、また国際的な基調演説者の最新研究に触 れる機会もあり今後のエコツーリズムの展開を世界的に模索する 機会であった。現在でも、オーストラリアにおいてエコツーリズ ムを発展させる組織として EAA の存在が大きい。EAA は民間団体 組織であるが、州、連邦政府の資金的な援助があってここまで発 展してきた。この発展により、オーストラリアは世界的にもエコ ツーリズム先進国といわれる所以である。EAA は、近年、温暖化 対策、二酸化炭素削減等での環境保護等も進めている。NEAP 認 証制度と向かう方向性は共通であるが、今後も、自然保護が優先 であり、より促進していくことが重要となっている。

\section{(4) NEAP 認証の手続き}

1）申請から認証までの流れ 
表-2 認証の条件

\begin{tabular}{|c|c|c|c|}
\hline エコツーリズム製品について & $\begin{array}{l}\text { ネイチャー } \\
\text { ツーリズム }\end{array}$ & $\begin{array}{c}\text { エコツーリズ } \\
厶\end{array}$ & $\begin{array}{l}\text { アドバンス } \\
\text { ッーリズム }\end{array}$ \\
\hline $\begin{array}{l}\text { 直接自然体験することによって興味や関心 } \\
\text { を抱かせるよ個性的なプログラムがある }\end{array}$ & $\mathrm{O}$ & O & $\mathrm{O}$ \\
\hline $\begin{array}{l}\text { 自然体験する時、正しく理解できるような方 } \\
\text { 法で自然しみ䄸がる方法がある }\end{array}$ & 任意 & \begin{tabular}{|c} 
必ずしも体験 \\
が中心の必 \\
要はない
\end{tabular} & $\begin{array}{c}\text { 体験が中心 } \\
\text { の要素であ } \\
\text { る } \\
\end{array}$ \\
\hline $\begin{array}{l}\text { 環境に最も良い持続的な観光にやり方を示 } \\
\text { し、実践してること }\end{array}$ & $\mathrm{O}$ & 0 & $\mathrm{O}$ \\
\hline 積極的に自然地域の保全に貢献する & & $\mathrm{O}$ & $\mathrm{O}$ \\
\hline 地元地域の貢献に献身的に継続し提供する & & O & O \\
\hline $\begin{array}{l}\text { 利用者に対し地域の文化を通し興味を持っ } \\
\text { てもらえるようにする }\end{array}$ & & $\mathrm{O}$ & O \\
\hline いつも利用者の期待を満たしている & $\mathrm{O}$ & $\mathrm{O}$ & $\mathrm{O}$ \\
\hline $\begin{array}{l}\text { エコツーリズム商品を現実的な予想に基づ } \\
\text { いた正確なマーケテイングできている }\end{array}$ & $\mathrm{O}$ & $\mathrm{O}$ & $\mathrm{O}$ \\
\hline
\end{tabular}

出典:EAA(2003) Nature and Ecotourism Certification Program Second editionより作成

NEAP 認証制度はEAA によって管理され、協会内の NEAP 実行委 員会で書類申請が行われ、EAA から独立した第三者機関NEAP 管理 集団で審査、評価を受け、最終的にオーストラリアエコツーリズ ム委員会で承認され、EAAに認証される。EAAから独立した第三者 機関を設けることでッアーオペレーターとの利害関係の防止にな り、更にその認証の信頼性にも繋がっている。

申請から認証までの流れは、図 - 1 に示した。認証を受けるた めにツアーオペレーターは、EAA が独自に作成した書類をインタ 一ネット上から入手し、記入を行う必要がある。書類は(a) 申請書 と (b) 自己評価書からなり、申込者の名前、住所など必要となる個 人情報に加え、NEAP 認証制度で定める商品分類（宿泊施設、ツア 一、アトラクション) とランク（ネイチャー、エコツーリズム、 アドバンスエコツーリズム) を商品の基準に基づきすべて自己評 価で判断し記入を行う。

次に(b) 自己評価書類は 150 ページを超え、大きく 8 つ項目に 分かれた質問事項に対し 4 段階評価で自己評価を行う。8つの項 目に関しては、自然地域、インタープリテーション、継続的な環 境保護への貢献、地域社会のための仕事、文化的構成要素、旅行 者の満足、責任のあるマーケティングである。これらの項目には、 それぞれ評価基淮とボーナス基準 43) があり、基準を満たし、ボ 一ナス基淮を満たすと評価の高いランクの認証を受けることが可 能となる。また必要に応じコメントや説明を加えた写真、レポー 卜を提出すると、ボーナス点に繋がる場合がある。

申請後、EAA の中の NEAP 実行委員会で審査が行われる。申請商 品に関して提出した自己評価書類を基に 8 つ項目からなる質問 事項から無作為に抽出し審査が行われる。申請書の内容、認証さ れる商品数、提出された書類の量等によって変わることもあるが 審査に要する期間は、約 14 日間としている。これらの審査をまと め委員会に提出をする。NEAP 管理集団では、審査をもとに監査と 評価を独自に行い、結果をオーストラリアエコツーリズム委員会 に提出する。審査に応じてさらに情報提出が求められることが 往々にある。

最終決定は、毎月開かれるオーストラリアエコツーリズム委員 会での判断によって決められ、その中で評価基準を満たしていな いものに関しては、申請が却下される。評価に総合的に合格する と認証を受けることが可能となる。認証期間は 3 年間である。そ のため 1 年ごとに報告書の提出、年会費の納入が義務付けられて いる。そして 3 年目が終わる時には、経営者は再度申請を行うか 退会するかを選択する。再度申請寸る場合は、改めて審査は行わ れる。

\section{表-3 認証料金}

\begin{tabular}{|c|c|c|c|c|c|}
\hline 毎年の売上高 & $-\$ 250,000$ & \begin{tabular}{|c|}
$\$ 250,001$ \\
$-\$ 1,000,000$
\end{tabular} & $\begin{array}{c}\$ 1,000,001 \\
-\$ 5,000,000\end{array}$ & \begin{tabular}{|c|}
$\$ 5,000,001$ \\
$-\$ 10,000,000$ \\
\end{tabular} & $\$ 10,000,001-$ \\
\hline 登録料 & \multicolumn{5}{|c|}{$\$ \$ 90$} \\
\hline 評価料金 & $\$ 295$ & $\$ 355$ & $\$ 460$ & $\$ 555$ & $\$ 760$ \\
\hline 年会費 & $\$ 335$ & $\$ 530$ & $\$ 770$ & $\$ 930$ & $\$ 1,040$ \\
\hline EAA割引会員 & $\$ 135$ & $\$ 175$ & $\$ 240$ & $\$ 400$ & $\$ 795$ \\
\hline
\end{tabular}

\section{2) 認証条件}

応募するにはネイチャーツーリズム、エコツーリズム、アドバ ンスツーリズムの申請分野がある。表 - 2 に認証対象条件の違い を示した。ネイチャーツーリズムは、自然地域における体験を大 切とした持続可能な観光である。また、訪れた自然地域の環境に 負荷を与える影響を最小限度にすることが求められる。

エコツーリズムは、自然地域における体験や文化的な理解、環 境保護管理の正しい理解を助長させることを大切とした持続可能 な観光である。また、自然地域の中で旅行者が楽しめるものを提 供し、経営者が環境資源を有効に利用し地域の社会に役立ち環境 保全に貢献することを求められる。アドバンスエコツーリズムは、 NEAP 商品の中での最高ランクとなる。経営者は、オーストラリア の中で最も有力なエコツーリズム商品として提供し続け、誰に対 しても最も良い業務を行い、環境資源を有効に利用寸る際に環境 保全の貢献と地域社会の助けに役立つことが求められる。この 2 つの違いでアドバンスエコツーリズムは、インタープリテーショ ンを最も重要な要素としていることと、突起した(特色のある) 実 践内容が示されていること、が違いになると示されている。

3) 認証対象商品

NEAP の認証を受ける商品には、宿泊施設、ツアー、アトラクシ ヨンがある。宿泊施設には、ロッジ、リゾート、キャンプ・キャ ラバングラウンドなどが含まれる。ツアーには、例えばブッシュ ウオーキング、ドライビング、洞窟探検、シュノーケルなどがあ る。旅行者は 1 つツアーだけでなく多くツアーへの参加など、 複数の活動を組み合わせることができる。ツアーで宿泊施設を利 用する場合でも、宿泊施設はツアーとは別に認証を受ける。アト ラクションとは、野生生物公園、サンクチュアリ（禁猟区・鳥獣 保護区など）、水族館、ビジターセンターなどが含まれる。アトラ クションは自然環境と設備を組み合わせていることが必須であり、 旅行者に対して体験や学習の助けをしなければいけない

\section{表-4 認証商品数}

\begin{tabular}{|c|c|c|c|c|c|c|c|c|c|c|}
\hline & タスマーフ & \begin{tabular}{|l} 
I-ザン \\
テリ忓
\end{tabular} & $\begin{array}{l}\text { 南オー } \\
\text { スト } \\
\text { リア }\end{array}$ & $\begin{array}{l}\text { 西オー } \\
\text { ストラ } \\
\text { リアア }\end{array}$ & $\begin{array}{l}=ュ ー サ \\
\text { ウスウx } \\
\text { ールス }\end{array}$ & $\begin{array}{l}\text { ビクト } \\
\text { リア }\end{array}$ & $\begin{array}{l}\text { クイズ } \\
\text { ラシト゚ }\end{array}$ & 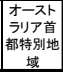 & 合計 & 其成率 \\
\hline ネイチャーツーリズム & 1 & 0 & 3 & 2 & 4 & 4 & 2 & 0 & 16 & $17 \%$ \\
\hline エコツーツーリズム & 1 & & 2 & & 3 & & 10 & & 24 & $26 \%$ \\
\hline トドバンスエコツーリズム & 3 & & 4 & & 8 & & 28 & 1 & 53 & $57 \%$ \\
\hline 宿泊施設計 & 5 & 4 & 11 & 7 & 15 & 10 & 40 & 1 & 93 & $22 \%{ }^{*}$ \\
\hline ネイチャーツーリズム & 1 & 8 & 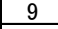 & 12 & 5 & 8 & 9 & 0 & 52 & $19 \%$ \\
\hline エコツーツーリズム & 4 & y & $y$ & 13 & 10 & 14 & 28 & 0 & 87 & $31 \%$ \\
\hline アドバンスエコツーリズム & 4 & 10 & 16 & 11 & 12 & 17 & 71 & 0 & 141 & $50 \%$ \\
\hline "アー計 & 9 & 27 & 34 & 36 & 27 & 39 & 108 & 0 & 280 & $66 \%{ }^{*}$ \\
\hline ネイチャーツーリズム & 0 & 0 & 0 & 2 & 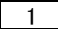 & 1 & 0 & 0 & 4 & $8 \%$ \\
\hline エコツーツーリズム & 1 & 2 & 2 & 4 & 0 & 3 & 0 & 0 & 18 & $36 \%$ \\
\hline Pドバンスエコツーリズム & 1 & 1 & 3 & 1 & 4 & 5 & 12 & 1 & 28 & $56 \%$ \\
\hline アトラクション計 & 2 & 3 & 5 & 7 & 5 & $\mathrm{~g}$ & 18 & 1 & 50 & $12 \%{ }^{*}$ \\
\hline ネイチャーツーリズム & 2 & 8 & 12 & 16 & 10 & 13 & 11 & 0 & 72 & $17 \%$ \\
\hline エコツーツーリズム & 6 & 14 & 15 & 18 & 13 & 19 & 44 & 0 & 129 & $30 \%$ \\
\hline アドバンスエコツーリズム & 8 & 12 & 23 & 16 & 24 & 26 & 111 & 2 & 222 & $52 \%$ \\
\hline 合計 & 16 & 34 & 50 & 50 & 47 & 58 & 166 & 2 & 423 & $100 \%{ }^{*}$ \\
\hline 認証比率 & $4 \%$ & $8 \%$ & $12 \%$ & $12 \%$ & $11 \%$ & $14 \%$ & $39 \%$ & $0 \%$ & $100 \%$ & \\
\hline
\end{tabular}

* 宿泊施設計、ツアー計、アトラクション計を合計すると $100 \%$ となる。 出典: EAA, < http://www.ecotourism.org.au/> (2010年1月時点)より作成 


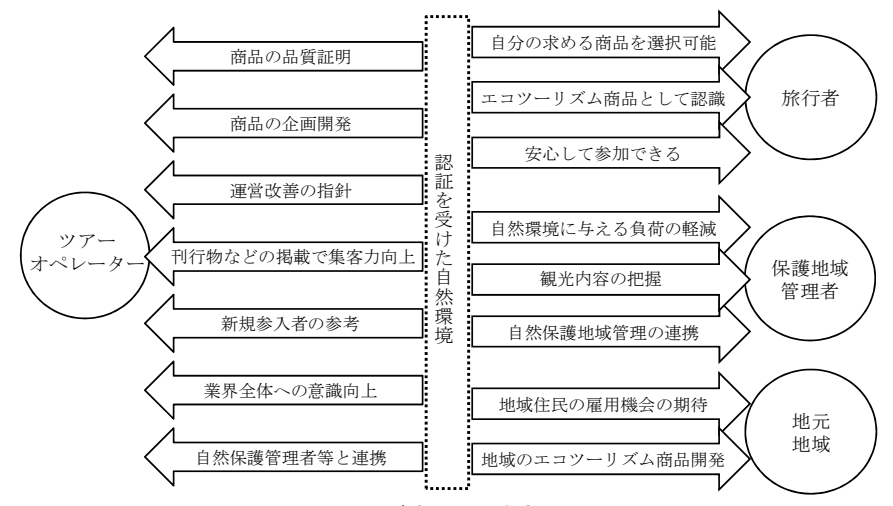

図-2 認証がもたらす効果

4）認証料金と認証商品数

認証を受けるには、登録料として 990 を支払い、その商品の総 年間売上高に基づいた評価料金と年会費を支払う必要がある（表

-3)。年会費は、その商品の出来高に応じた支払い形式にするこ とでッアーオペレーターの経済的な面て配慮しており、認証を受 けるための取り組みがしやすい設定と考えられる。

認証商品数は、2010年 1 月時点で 423 個取得している(表-4)。 その大半は最高ランクであるアドバンスエコツーリズムの適性を 積極的に取得していることから、多くのツアーオペレーターは認 証の付加価值が高いことを認識していると考えられる。また認証 を受ける商品種類の 6 割をツアーが占めている。これは旅行業者 も多く認証を取得しているためツアー企画が多いといえる。そし て州別に認証数を見るとクイーンズランド州が最も商品が多くあ ることがいえる。これはクイーンズランド州には、世界遺産地域 や国立公園が多いだけでなく都市から比較的にアクセスがしやす いことて集客効果が高いからだといえる。更にクイーンズランド 州は、エコツーリズム州と銘打ってエコツーリズムが盛んで州政 府の方針でも整備を積極的に進めていることや NEAP 認証制度を 行うEAA の事務所がクイーンズランド州あることも影響寸ると考 えられる。

\section{（5）NEAP 認証制度がもたらす効果}

NEAP 認証制度のもたらす効果は、NEAP 認証制度のマニュアル 23) に記載されている効果を、4つの立場ごとに整理して図 - 2 に 示した。4つの立場とは、(1)ツアーオペレーター、(2)旅行者、(3) 保護地域管理者、(4)地元地域である。それぞれの立場ごとに期待・ 要求・役割があり、その効果は共通の観光資源となる自然環境か ら見出されたものである。

NEAP 認証制度がもたら寸効果をツアーオペレーターから整理 したのが、図 - 2 の左側である。まず、商品が認証されることに より、商品の品質が証明される。また、認証を受けるための取り 組みから、運営計画や商品の企画開発が進み集客力の向上に繋が る効果が期待できる。新規参入者にとっても、商品の参考となり、 業界全体での意識向上につながる。さらに、自然環境に配慮した 取り組みは、自然保護管理者との連携につながる。連携の広がり は、産業を活性化させるだけでなく、自然環境に対しても配慮し た商品が期待できる。保護地域管理者にとっても、NEAP 認証を受 けた商品が増えることにより自然環境に与える負荷が軽減する。 地元地域にとっても、認証商品が増えることにより雇用機会の創 出や関連グッズなどの開発が期待できる。

一方で、国際エコツーリズム協会の報告によれば、環境保護は 宿泊施設の責任と認識している旅行者が多い。米国、オーストラ リア旅行者の 3 分の 2 以上が、イギリスの旅行者の $90 \%$ 以上が、 環境保護への取り組みに対して宿泊施設の責任を認識している ${ }^{44)}$ NEAP のツアーオペレーターには宿泊施設の責任者も含まれてお
り、ツアーオペレーターの環境保護に対する取り組みは、重要で ある。旅行者にとっても、認証商品が増えることで旅行者の好み に合わせた選択肢の幅が広がる。

\section{(6) NEAP 認証の効果の検証}

NEAP 認証を受けるために実施されるマニュアルは、大きく8つ の項目 ${ }^{45}$ に分か氺、(1)自然地域重視、(2)インタープリテーション、 (3)持続可能な環境、(4)保護への貢献、(5)地域社会のための仕事、 (6)文化的構成要素、(7)旅行者の満足度、8責任あるマーケティン グ、で規格基淮を満たしているかをチェックするものである。対 象は、アドバンスエコツーリズム（最高ランクの認証を受けた商 品）に佂るッアー16'宿泊施設 17?、アトラクション ${ }^{18}$ て現地 調査を実施した。現地調查結果から分かった項目を以下にまとめ た。なお、調查者の主観的な意見もあるが参考のために記入した。

NEAP 認証商品は、旅行者に対して高、信頼性を示寸ものである。 理由は、NEAP 認証制度の重要な 8 つ項目からの規格基淮を満た すことで環境配慮への取り組み度合いを判断する材料となる。更 にNEAP 認証は、独立した第三者機関によって監查を受け、ツアー オペレーターとの利害関係が生まれないようにすることで、信頼 性はより高い付加価值に繋がる。その結果としてその信頼性は、 旅行者が選択寸る時に安心して参加でき、求める要求を満たして くれ、值段だけでなく自然環境に配慮した認証ラベルが貼ってあ ることでエコツーリズムを期待する旅行者を引き付ける効果があ る。しかし、NEAP認証の最高ランクの認証受けていながらも現地 調查では大きく 3 つの問題点を感じた。

第一の問題点としては、NEAP 認証制度についての現地宿泊施設 スタッフの認識不足が考えられる。現地で、スタッフに直接イン タビューをした結果、NEAP 認証制度を知らないスタッフもいた。 また、現地調查から、ゴミの分別処理が適切に行われていない事 例が見られた。NEAP認証の取り組みは、経営者判断で行われるた め、経営者らの上位者は、十分理解と認識老持っているが、末端 のスタッフにまでは十分浸透していない事例があった。

第二の問題点としては、ッアー企画の書類上では適切に基準を 満たしているが、実際は、多人数が一度に移動している問題があ った。現地調査では、移動手段はバス 1 台に 50 名以上の旅行者が 一緒に体験を行った。ツアーは旅行者約 10 名に対し、ガイドが 1 人付く形で 5 組の団体で実施し、書類上は最高ランクの認証にあ たる基淮を満たす形をとっている。しかし、ツアー内容はそれぞ れの団体との時間を空けることなく、ほとんど 1 つ団体が一緒 に移動する形であった。ツアーオペレーターにとっては、1 台の バスを使い多くの旅行者を運ぶことでコストダウンに繋がり合理 的でもあるが、NEAP 認証制度は、本来エコツーリズムを推奨する ものであるため、環境配慮へ取り組むためには、少人数制を選択 すべきと考える。利用者 10 名ごとにガイドが 1 名付いても、ツア 一が 5 組同時に集まれば 50 名になり、解説活動の画一化が進む。 例えば、同じバスで移動する場合は、5 組の団体それぞれが同じ 時間で移動していく必要がある。このため、解説が画一化してし まう弊害がある。旅行者の興味や実際の自然の変化に対寸る臨機 応変な解説活動ができなくなることが問題である。しかし、ツア 一の現地解説において、旅行者 10 名に対しガイドが 1 人付くこと は評価できる。ガイドの声を旅行者が十分に聞ける人数であった。

第三の問題点としては、NEAP 認証制度の取得のための手間と時 間が長いので、今後より時間の短縮を検討すべきである。現地の スタッフが指摘していたが習得するための認証の流れがシンプル になることでより早い認証を得ることが可能となる。ホームペー ジを使った申請 ${ }^{24)}$ などの改善は行われているが、まだ、制度の認 証過程での手間と時間の負担があり、応募しにくいことが原因に 繋がっているかもしれない。オーストラリアは、観光を国の主産 業としており、今後も自然環境を重視したエコツーリズム産業の 
育成が重要である。そこで、今後さらに認証をスムーズに与える ことて環境に配慮するツアーオペレーターの増加に繋がるのでは ないかと考える。

\section{4. まとめ}

NEAP 認証制度の成立過程の特徴をまとめた。オーストラリアの 観光事業は国の基幹产業である。NEAP 認証制度の仕組みは 1996 年から開始し、料金体系や制度基淮の改善、新しいシステムの導 入について現在に至るまで試行錯誤を繰り返し実施してきたこと で、NEAP 認証制度の環境配慮への取り組み度合いを判断寸る材料 となった。更に、制度が成立した背景として、国や州が戦略的に エコツーリズムを推倠している。NEAP 認証制度の設立段階では、 国や州の資金援助が有効に活用され、認証制度を開始することが できた。現在では、年会費や認証料金などが一定額入るようにな っており、より国や州から独立した資金源を持つようになった。 NEAP 認証制度を設けることにより、観光事業の資源である自然環 境保護に役立っているといえる。

次に、NEAP 認証制度の認証の特徴をまとめた。NEAP 認証は、独 立した第三者機関によって監查を受け、ツアーオペレーターとの 利害関係が生まれないようにすることで、より信頼性の高い価值 観に繋がった。その結果としてその信頼性は、旅行者が選択寸る 時に安心して参加でき、求める要求を満たしてくれ、值段だけで なく自然環境に配慮した認証があることでエコツーリズムを期待 する旅行者を引き付ける効果が生まれた。NEAP認証制度の信頼性 は、制度の仕組み的にも高いことが分かった。

最後に、商品認証の実態をまとめた。現地調查からいくつかの 問題点があった。特に、NEAP 認証制度の取り組みについての認識 が末端のスタッフにまで伝わっていないことがあった。今後、認 証商品を扱うスタッフへの教育についても検討が必要である。ま たツアーの場合、認証のための書類上では適切に基淮を満たして いるが、バスなどでの移動手段で、複数のツアーをまとめて運ぶ ような事例もあり、今後の検討課題の一つである。また、NEAP 認 証制度の取得のための手間と時間が長いので、認証基淮と手順の 検討を進め、申請者の負担を削减する工夫を重ねるべきであろう。

NEAP 認証制度は、国や州、ツアーオペレーター、保護地域管理 者、地元地域が連携した取組みである。自然環境保護に配慮した この認証制度を、今後も継続的に推倠することがオーストラリア のエコツーリズム発展に繋がると考える。

本論文で得られた成果は、現地調査、インタビューによるもの が大きい。現地でご協力頂いたスタッフの皆さんに感謝したい。

補注及び引用文献

1）海津ゆりえ (2008) :国立公園における新たな試み「エコツーリズム」:森林科学 53, 27-31

2）下村彰男（2004）:エコツーリズム さあ、はじめよう！:財団法人日本交通公社,平 凡社, 185-186

3) Ralf C. Buckley ( 2001 ) : Ecotourism Accreditation in Australia : Tourism ecolabelling ,certification and promotion of sustainable management, Xavier Font \& Ralf Buckley Chapter11, 165-173

4) Guy Chester and Alice Crabtree (2002): Australia, The Nature and Ecotourism Accreditation Program:Ecotourism \& Certification Setting Standards in Practice, Martha Honey, Island Press,Chapter5,161-185

5) J.-P.lssaverdis (2001) : The Pursuit of Excellence, Benchmarking, Accreditation, Best Practice and Auditing : The Encyclopedia of Ecotourism, David B. Weaver, CAB International, Cheapter37, 579-591

6) John Jenkins and Stephen Wearing (2003) : Ecotourism and Protected Areas in Australia : Ecotourism Policy and Planning, David A. Fennell \& Ross k. Dowling, CAB International, Chapter11, 205-233

7) Rik Thwaites (2007) : The Australian EcoCertification Program(NEAP), Blazing a Trail for
Ecotourism Certification, but Keeping on Track? : Quality Assurance and Certification in Ecotourism, Rosemary Black \& Alice Crabtree, CAB International, Chapter22, 435-463

8）小林寛子 (2002) : エコツーリズムってなに?フレーザー島からはじまった挑戦: 河出書房新社, $251 \mathrm{pp}$

9） スー・ビートン (2002) : エコツーリズム教本 先進国オーストラリアに学ぶ実践 ガイド : 訳小林英俊, 平凡社, $317 \mathrm{pp}$

10）小林英俊（2006）：自然遺産管理とツーリズムが共存する仕組み, 国立民族学博物 館調査報告 $61,167-197$

11) Commonwealth of Australia.

12）二ューサウス・ウェールズ、ビクトリア、クイーンズランド、南オーストラリア 西オーストラリア、タスマニア。

13）北部淮州ノーザンテリトリー、首都特別地域。

14）シドニー日本商工会議所 (2009) オーストラリア概要, p. 7

15）日本貿易振興機構（ジェトロ）オーストラリア $<$ http://www.jetro.go.jp/world/oceania/au/stat_01>,2010.8.26 参照.

16）宿泊施設は、オライリーゲストハウスに宿泊。

17）ツアーは、ツアーゴールドコーストが主催する土ボタルツアーに参加

18）アトラクションは、カランビン・ワイルドライフ・サンクチュアリー (動物保護 区) に訪問した。

19) NEAP: Nature and Ecotourism Accreditation Program の略

20) EAA: Ecotourism Australia Association $の$ 略

21）前掲 8), p. 53

22) Australian Tour Operators Network (ATON), Victorian Tour Operators Association (VTOA) と引用先によっては異なるが、お互いは対応寸るものでここではオーストラリア ツアーオペレーターネットワーク (ATON /VTOA) と記載する。

23) Ecotourism Australia(2003) : Nature and Ecotourism Certification Program, : Second edition, p.3

24） EcotourismAustralia HP から $<$ http://www.ecotourism.org.au/index.asp $>, 2010.8 .18$ 参照

25）ツアーオペレーターとは、観光業に携わる多くの関係者を示しているが、日本語 では適切な訳がないため本論では、そのままの形を使用する。

26) Wet Tropics Management Authority (2004) :AHandbook for Tour Guides Daintree River to Cape Tribulation, p.4

27) K.A.Matysek \& L.K.Kriwoken (2003) : The Nature State: Nature-Based Tourism and Ecotourism Accreditation in Tasmania, Australia: Journal of Quality Assurance in Hopitality \& Tourism, Vol.4(1/2) ,p.8

28）前掲 4), p. 163

29) Tsung-Wei Lai (2002) : Ecotourism in Australia: Linking Green Productivity to Ecotourism, Experiences in the Asia-Pacific Region, Cheapter32, p.270

30) Dr Ross K. Dowling, Selected List of Conferences, $<$ http://ideology.net.au/file_download/1/ Dowling+Conferences.pdf $>, 2010.9 .19$ 参照

31）前掲4), p. 164

32）前掲 27), p. 54

33）前掲 7), p. 435

34）前掲 7), p. 436

35）前掲 7), p. 438

36）前掲 7), p. 448

37）前掲 27), p. 55

38）前掲 7), p. 446

39） NEAP 認証制度は、2003 年の改正でEcoCertification Programに名称を変更した。こ のため、2010 年現在でNEAPの名称を使用していないが、本論文ではEcoCertification Program も NEAP 認証制度として呼ぶことにした。

40) Ralf Buckley(2002) : Research Note Tourism Ecocertification in the International Year of Ecotourism, Journal of Ecotourism, Vol. 1, p.197

41）前掲 40), p. 197. 認定 (Accreditation) は、競合し合う団体によって認定が異なり、 旅行者には判断が難しいと考えられている。また認証（Certification）は、公の 機関が正当な手続きによって運用されることで信頼性が高く、より実効性も高い ものを示し、エコ認証 (Ecocertification) は、環境保護の活動に対して認証するも のである。そのため用語の使用方法は、認定より認証を使用することが多い。

42) Global Eco Asia Pacific Conference 2010 について $<$ http://www.globaleco.com.au/>, 2010.9.15 参照

43）ボ一ナス基淮とは、基淮にある質問事項とは別にある、より高度な要求に対して 達成寸ることで与えられるポイントである。例としてガイド 1 人あたり 5 人未満 の利用者といった人の制限や、自然エネルギー（電気自動車、太陽光）の完備、 トイレのコンポスト化の設備の強化などがあげられている。

44) The International Ecotourism Society (2005) : Fact Sheet, Global Ecotourism, p.2

45）前掲23), $17-120$ 